\title{
Evaluation of HbxRBC product as a screening method in sickle cell Anemia
}

\author{
Jawarkar A. ${ }^{1}$, Agrawal A. ${ }^{2}$ \\ ${ }^{1}$ Dr. Ashish Jawarkar, Assistant Professor, ${ }^{2}$ Dr. Aakanksha Agrawal, Tutor; both authors are attached with Department of \\ Pathology, Parul Institute of Medical Sciences and Research, Vadodara.
}

Corresponding Author: Dr. Ashish Jawarkar, Assistant Professor, Department of Pathology, Parul Institute of Medical Sciences and Research, Vadodara. Email: pathologybasics@gmail.com

\begin{abstract}
Background: India has been ranked the second worst affected country in terms of predicted SCD births. In developed countries, new-born screening programs have been established to ensure early diagnosis, but in most developing countries, screening is not performed, and the diagnosis is often delayed. Aim of present study was to analyse the effectiveness of Hb*RBC product as a screening tool. Methods: In the present study, blood from 200 patients suspected to have Sickle cell hemoglobinopathies was analysed and subjected it to Sickling screening test. All positive cases were subjected to HPLC to separate constituent haemoglobins and $\mathrm{CBC}$ analysis was done to check RBC indices. Hb*RBC product was analysed. Results: Analysis of $\mathrm{Hb} * \mathrm{RBC}$ product revealed that there was a statistically significant difference in values between controls and disease patients. $\mathrm{Hb} * \mathrm{RBC}$ product had good sensitivity and specificity in predicting sickle cell disease. Conclusions: $\mathrm{Hb} * \mathrm{RBC}<45 \mathrm{was}$ sensitive and specific predictor of sickle cell disease and can be used as a screening tool. Patients with this finding should be further subjected to specific tests like $\mathrm{Hb}$ electrophoresis for confirmation.
\end{abstract}

Keywords: Sickle cell anemia, $\mathrm{Hb} * \mathrm{RBC}$, Sickle cell disease

\section{Introduction}

Sickle cell disease (SCD) is an autosomal recessive disorder [1] resulting from single base $A>T$ mutation in the triplet encoding the sixth residue of the $\beta$-globin chain, leading to a substitution of valine for glutamic acid and the abnormal haemoglobin $\mathrm{S}(\mathrm{HbS})$. The disease is expressed when Haemoglobin $\mathrm{S}(\mathrm{HbSS})$ is inherited from both parents, the homozygous patient or HbSS suffers from sickle cell anaemia, while the heterozygous child or Haemoglobin AS (HbAS) is a carrier of a sickle cell trait [2]. Individuals with SCD experience considerable morbidity. Without effective treatment, the most severe cases can be fatal within the first few years of life.

The primary pathophysiology is based on formation of long fibres within the Red Blood Cells (RBCs) causing a distorted sickle shape which eventually leads to haemolysis and vaso-occlusion. There are several events that may trigger vaso-occlusion. Recent work has shown the importance of red cell dehydration, abnormal adhesion of RBCs to the vascular endothelium, inflammatory events, and activation of all the cells in the vessel and abnormalities of nitric oxide metabolism in the pathophysiology of this multi-organ disease. [3]

India has been ranked the second worst affected country in terms of predicted SCD births [4]. In India, SCD is distributed geographically in the central and western regions [5,6]. As per an Indian Council of Medical Research survey, about $20 \%$ of children with SCD expired by age of two and $30 \%$ of children with SCD among the tribal community die before they reach adulthood [7,8]. Particularly in Gujarat, studies indicate a higher percentage of Sickle cell disease prevalence versus sickle cell trait [9].

In developed countries, new-born screening programs have been established to ensure early diagnosis, but in most developing countries, screening is not performed, and the diagnosis is often delayed. Aim of present study was to analyse the effectiveness of $\mathrm{Hb} * \mathrm{RBC}$ product [10] as a screening tool.

\section{Methods}

Setting- This study was done in a tertiary care hospital in Western Indian city of Vadodara, Gujarat on an outpatient basis. Duration- Study was carried out for a period of two years from 2017 to 2018.

Manuscript received: $10^{\text {th }}$ October 2019

Reviewed: $20^{\text {th }}$ October 2019

Author Corrected: $30^{\text {th }}$ October 2019

Accepted for Publication: $6^{\text {th }}$ November 2019

Pathology Update: Tropical Journal of Pathology \& Microbiology Available online at: www.medresearch.in 868 | P a g e 
Sampling method and size- The study population consisted primarily of tribals from Central Gujarat and southern Madhya Pradesh. Venous blood (2ML) was collected in EDTA bulb under aseptic conditions from 200 patients suspected of having sickle cell hemoglobinopathies (i.e. patients suffering from anemia, joint pains, weakness, abdominal pain etc.).

Inclusion and exclusion criteria- $2 \mathrm{ml}$ venous blood in EDTA bulb was subjected to sickling test. 151 patients showed sickling test positive and were selected as cases. Also, blood was collected from the 40 normal healthy individuals and subjected it to the same tests as above. They were sickling test negative and were selected as controls. Cases and controls further underwent a CBC examination and HPLC to separate constituent haemoglobins.

The following criterial were used to identify hemoglobinopathies on HPLC patterns [10] (Table 1).

Table-1 Criteria used for differentiating HPLC patterns

\begin{tabular}{|l|c|}
\hline Hemoglobin & Disease \\
\hline $\mathrm{A}>\mathrm{S}$ & Sickle cell trait, sickle alpha-thalassemia \\
\hline $\mathrm{S}, \mathrm{F}$ and no $\mathrm{A}$ & Sickle cell disease, Sickle-beta thalassemia \\
\hline $\mathrm{S}>\mathrm{A}$ and $\mathrm{F}$ & Sickle - beta thalassemia \\
\hline $\mathrm{A}>\mathrm{C}$ & HbC trait \\
\hline $\mathrm{C}, \mathrm{F}$ and no A & HbC disease, HbC-beta thalassemia \\
\hline $\mathrm{C}>\mathrm{A}$ & HbC - beta thalassemia \\
\hline
\end{tabular}

49 patients who were negative by sickling test were excluded from the study.

Data collection procedure- Data was collected from patients case files from medical records section.

Data analysis- Continuous variables were presented as mean+/-2SD. Continuous variables were compared between cases and controls by performing unpaired $t$ test. Categorical variables were compared by performing chi square statistics. $\mathrm{P}<0.005$ was statistically significant. Microsoft excel and GraphPad calculator was used for data analysis.

Ethical consideration \& permission- All ethical considerations and permissions were obtained from concerned authorities.

\section{Results}

Out of 200 patients suspected of having sickle cell anemia, 151 tested positive by sickling test. Analysis of HPLC patterns revealed the following findings. 58 patients were having sickle cell trait (AS) (38.9\%), 83 showed sickle cell disease (55.7\%) (SS), 2 were diagnosed to have $\mathrm{HbS}$ due to recent transfusion and 8 were sickle beta thalassemia (S $\beta)(5.3 \%)$. The latter two categories were not included in the present study.

Both sickle cell trait and sickle cell disease patients had significantly lower levels of $\mathrm{Hb}$ as compared with controls. Analysis of $\mathrm{Hb}$ in cases versus controls is shown in Table 2.

Table-2: Hb in sickle cell anemia patients versus controls

\begin{tabular}{|c|c|c|c|c|c|}
\hline & N & Mean & SD & pvalue & significance \\
\hline Control & 40.0 & 13.3 & 1.4 & & \\
\hline SCT & 58.0 & 11.0 & 4.8 & 0.0049 & yes \\
\hline SCD & 83.0 & 8.0 & 1.8 & $<0.0001$ & yes \\
\hline
\end{tabular}

The difference in RBC counts was not statistically significant between controls and both sickle cell trait and sickle cell disease patients. Analysis of RBC count in cases versus controls is shown in Table 3.

Table-3: RBC count in sickle cell anemia patients versus controls

\begin{tabular}{|c|c|c|c|c|c|}
\hline & N & Mean & SD & P value & significance \\
\hline Control & 40 & 3.67 & 0.54 & & \\
\hline SCT & 58 & 4.19 & 1.29 & 0.0181 & no \\
\hline SCD & 83 & 3.29 & 0.98 & 0.0239 & no \\
\hline
\end{tabular}

Pathology Update: Tropical Journal of Pathology \& Microbiology Available online at: www.medresearch.in 869 | P a g e 
Analysis of $\mathrm{Hb} * \mathrm{RBC}$ product revealed that difference in $\mathrm{Hb} * \mathrm{RBC}$ product is statistically significant between controls and sickle cell disease patients. It was not significant in sickle cell trait patients. Details are shown in Table 4.

Table-4: Hb*RBC count in sickle cell anemia patients versus controls

\begin{tabular}{|c|c|c|c|c|c|}
\hline & N & Mean & SD & P value & significance \\
\hline Control & 40 & 37.98 & 11.12 & & \\
\hline SCT & 58 & 34.74 & 32.48 & 0.5459 & No \\
\hline SCD & 83 & 21.77 & 16.04 & 0.0001 & Yes \\
\hline
\end{tabular}

\section{Discussion}

Sensitivity and specificity of $\mathrm{Hb} * \mathrm{RBC}<45$ was analysed to determine whether it can be used as a screening parameter in patients for patients of sickle cell disease. It was observed that it has $93.9 \%$ sensitivity and $95 \%$ specificity as a screening parameter. SCD is a major public health concern that has great impact on both individuals and society. Mortality associated with this disease is high despite knowledge of the pathophysiology [11,12]. and treatment of the various forms of crisis. Mortality from the disease is highest in the first 5 years of life, with approximately $50 \%$ of deaths occurring in the second 6 months of life [13-17].

For most affected children, the parents are usually unaware of the presence of the [13]. In developed countries, newborn screening programs have been established to ensure early diagnosis and thus early enrolment into a comprehensive healthcare program [18-23], but this screening is not performed in India and in most developing countries. If newborn screening programs are started, it is estimated that $85 \%$ children with SCD will survive upto 20 years of age with prophylactic penicillin administration [24]. In order to find a suitable and cheap screening method for study population, levels of hemoglobin, $\mathrm{RBC}$ count and $\mathrm{Hb} * \mathrm{RBC}$ product were analysed as a suitable alternative.

Both sickle cell trait and sickle cell disease patients had significantly lower levels of $\mathrm{Hb}$ as compared with controls. This corelates with various studies done by Walke et al and Chikhlikar et al $[25,26]$. The difference in RBC counts was not statistically significant in the present study between controls and both sickle cell trait and sickle cell disease patients. This is in contrast with studies by Chikhlikar et al [26], Pathak et al [27], and Yasmin et al [3]. Analysis of $\mathrm{Hb} * \mathrm{RBC}$ product revealed that difference in values for controls and trait patients was not statistically significant. There was a statistically significant difference between controls and disease patients. $\mathrm{Hb} * \mathrm{RBC}$ product had good sensitivity and specificity in predicting sickle cell disease. This was in concordance with study conducted by Valavi et. al [10]. The limitation of this study was simultaneous iron deficiency anemia in many of current patients. Studies on large population would be helpful to support the present observations.

\section{Conclusion}

$\mathrm{Hb} * \mathrm{RBC}<45$ was sensitive and specific predictor of sickle cell disease and can be used as a screening tool. Patients with this finding should be further subjected to more specific tests like $\mathrm{Hb}$ electrophoresis for confirmation.

\section{What this study adds to existing knowledge?}

From the present study it can be proposed that a simple $\mathrm{CBC}$ test should be done in all newborns. Analysis of their $\mathrm{Hb} * \mathrm{RBC}$ product can help in knowing the sickle cell disease status and further testing can be initiated in suspected cases. This can prevent long term mortality and morbidity and increase overall survival.

\section{Author's contributions}

Dr. Ashish Jawarkar: Data collection and assisting with writing of this manuscript.

Dr. Aakanksha Agrawal: Data analysis and manuscript preparation.

Funding: No funding sources

Conflict of interest: None declared

Ethical Approval: This study was approved by the Institutional Ethics Committee

\section{Reference}

1. Serjeant GR, Serjeant BE, editors. Sickle cell disease. 3rd ed. Oxford: Oxford Univ Press;2001

2. Wilson M, Forsyth P, Whiteside J. Haemoglobinopathy and sickle cell disease. Continuing Education in Anaesthesia, Critical Care\&Pain. 2009;10(1):24-28. doi:10. 1093/bjaceaccp/mkp038.

3. Khan Y, Thakur AS, Mehta R, Kundu RK, Agnihotram G. Hematological profile of sickle cell disease: a hospitalbased study at Cims, Bilaspur, Chhattisgarh. IJABPT. 2010; 1 (2):717-721.

4. Hockham C, Bhatt S, Colah R, Mukherjee MB, Penman BS, Gupta S, et al. The spatial epidemiology of sickle-cell anaemia in India. Sci Rep. 2018;8(1):17685. doi: 10. 1038/s41598-018-36077-w. 
5. Rao VR. Genetics and epidemiology of sickle cell anemia in India. Indian J Med Sci. 1988;42(9):218-222.

6. Jain DL, Sarathi V, Upadhye D, Gulhane R, Nadkarni $\mathrm{AH}$, Ghosh $\mathrm{K}$, et al. Newborn screening shows a high incidence of sickle cell anemia in Central India. Hemoglobin. 2012; 36(4):316-322. doi: 10.3109/03630269. 2012. 691434. Epub 2012 Jun 19.

7. Rupani MP, Vasava BC, Mallick KH, Gharat VV, Bansal R. Reaching community through school going children for sickle cell disease in Zankhvav village of Surat district, Western India. Online J Health Allied Sci. 2012;11(2).

8. Sickle Cell Anemia Control Project, Ahmedabad. Government of Gujarat 2012. Available at http:// www. sickle-cell.gujarat.gov.in/SC_Program.aspx. [Last accessed on 2016 May 28]

9. Jawarkar A, Bhatia V. A study of HPLC patterns in patients of sickle cell anemia with analysis of red cell parameters. Int J Res Med Sci. 2018;6(7):2390-2395. doi: http://dx.doi.org/10.18203/2320-6012.ijrms20182823.

10. Valavi E, Ansari MJ, Zandian K. How to reach rapid diagnosis in sickle cell disease? Iran J Pediatr. 2010; 20(1):69-74.

11. Odièvre MH, Verger E, Silva-Pinto AC, Elion J. Pathophysiological insights in sickle cell disease. Indian J Med Res. 2011;134(4):532-537.

12. Lane PA. Sickle cell disease. Pediatr Clin North Am. 1996;43(3):639-664. doi:10.1016/s0031-3955(05)70426-0.

13. Bunn HF. Pathogenesis and treatment of sickle cell disease. N Engl J Med. 1997;337(11):762-769. doi: 10. 1056 / NEJM199709113371107.

14. Bainbridge R, Higgs DR, Maude GH, Serjeant GR. Clinical presentation of homozygous sickle cell disease. J Pediatr. 1985;106(6):881-885.doi:10.1016/s0022-3476(85) 80230-4.

15.Williams S, Maude GH, Serjeant GR. Clinical presentation of sickle cell-hemoglobin C disease. J Pediatr. 1986;109(4):586-589. doi: https://doi.org/10.1016/S00223476 (86)80217-7.

16. O'Brien RT, McIntosh S, Aspnes GT, Pearson HA. Prospective study of sickle cell anemia in infancy. J Pediatr. 1976;89(2):205-210.doi: 10.1016/s0022-3476(76)80449-0.
17. Leikin SL, Gallagher D, Kinney TR, Sloane D, Klug P, Rida W. Mortality in children and adolescents with sickle cell disease. Cooperative Study of Sickle Cell Disease. Pediatr. 1989;84(3):500-508.

18. Thomas AN, Pattison C, Serjeant GR. Causes of death in sickle-cell disease in Jamaica. Br Med J (Clin Res Ed). 1982;285(6342):633-635. doi: 10.1136/bmj.285.6342.633.

19. Vichinsky E, Hurst D, Earles A, Kleman K, Lubin B. Newborn screening for sickle cell disease: effect on mortality. Pediatr. 1988;81(6):749-755.

20. Githens JH, Lane PA, McCurdy RS, Houston ML, McKinna JD, Cole DM. Newborn screening for hemoglobinopathies in Colorado. The first 10 years. Am J Dis Child. 1990;144(4):466-470. doi: 10.1001/archpedi. 1990.02150280088018 .

21. Vichinsky EP. Comprehensive care in sickle cell disease: its impact on morbidity and mortality. Semin Hematol. 1991;28(3):220-226.

22. Pearson HA. A neonatal program for sickle cell anemia. Adv Pediatr. 1986;33:381-400.

23. Scott RB, Harrison DL. Screening of the umbilical cord blood for sickle cell disease: utilization and implementation. Am J Pediatr Hematol Oncol. 1982 Summer; 4(2): 202-205.

24. Odunvbun ME, Okolo AA, Rahimy CM. Newborn screening for sickle cell disease in a Nigerian hospital. Public Health. 2008;122(10):1111-1116. doi: 10.1016/j. puhe. 2008.01.008. Epub 2008 May 19.

25. Walke VA, Walde MS. Haematological study in sickle cell homozygous and heterozygous children in the age group 0-6 years. Indian J Pathol Microbiol. 2007;50(4):901904.

26. Chikhlikar K, Wilkinson A. A study of red cell parameters in patients of sickle cell trait. IOSR J Dental Medical Sci. 2014;13(3):46-50.

27. Pathak K, Kishore S, Anshu, Shivkumar VB, Gangane $\mathrm{N}$, Sharma S. Study of haemoglobin S percentage and haematological parameters in sickle cell trait. Indian J Pathol Microbiol. 2003;46(3):420-424.

\section{How to cite this article?}

Jawarkar A, Agrawal A. Evaluation of HbxRBC product as a screening method in sickle cell Anemia. Trop J Path Micro 2019;5 (11): 868-871.doi:10.17511/jopm.2019.i11.06 